\title{
Estrous Signs and Progesterone Profile of Ongole Grade Cows Synchronized at Different Ages Fed Different Level of Dietary Crude Protein
}

\author{
R. N. Hayati ${ }^{a, *}$, Panjono ${ }^{b}, \&$ A. Irawan ${ }^{c}$ \\ aAssessment Institute for Agricultural Technology of Central Java \\ Jalan Soekarno Hatta KM.26 No.10, Tegalsari, Bergas, Kab. Semarang, Central Java 50552, Indonesia \\ ${ }^{\mathrm{b}}$ Faculty of Animal Science, Universitas Gadjah Mada \\ Jalan Fauna No. 03 Bulaksumur, Yogyakarta 55281, Indonesia \\ 'Vocational School, Universitas Sebelas Maret \\ Jalan Ir. Sutami No. 36 A Kentingan, Jebres, Surakarta 57126, Indonesia \\ *Corresponding author: rininur_bptp@yahoo.com \\ (Received 15-08-2020; Revised 24-09-2020; Accepted 13-10-2020
}

\begin{abstract}
This study aimed to evaluate the effects of concentrate supplementation containing different protein levels on estrous signs and progesterone profiles of two age groups of Ongole Grade cow. Thirty females cows were grouped according to their ages (G1= 25 \pm 1.6 months; G2= 37 \pm 1.7 months), where each group received 3 dietary treatments with 5 replicates. The dietary treatment was based on $\mathrm{CP}$ levels of total mixed ration (TMR) $(\mathrm{T} 1=7.41 \% \mathrm{CP} ; \mathrm{T} 2=8.23 \% \mathrm{CP}$; and $\mathrm{T} 3=9.17 \% \mathrm{CP})$. The cows were synchronized using PGF2 $\alpha$ and GnRH, followed by time-fixed artificial insemination (TAI) using frozen semen. Data on nutrient intake and progesterone concentration were subjected to a randomized complete block design of ANOVA following a factorial arrangement of $2 \times 3$ while data of estrous signs were analyzed using non-parametric methods of Kruskal-Wallis and independent t-test. The results showed that there was a significant interaction effect between age group and dietary TMR treatment on CP intake and TDN intake in which the highest intakes were found in older cows (G2) fed TMR at $7.41 \%$ CP (T1) $(p<0.01)$. Dry matter intake (DMI) was not affected either by age group or level of concentrate supplementation. Results also suggested that estrous signs, including vulva redness, swollen vulva, and mucus discharge, were higher in older cows (G2) than in younger cows (G1). In addition, interactions were also found on progesterone levels, whereas younger cows (G1) fed TMR with $9.17 \%$ CP (T3) showed the highest concentration of progesterone on $\mathrm{d} 5,17$, and $21(\mathrm{p}<0.01)$. In conclusion, this study suggests that younger cows receiving the highest $\mathrm{CP}$ diet (T3) result in higher progesterone concentration during the experimental period. Therefore, it is important to fed sufficient dietary CP especially for cattle in early reproduction period to optimize the reproductive performance.
\end{abstract}

Keywords: estrous; Ongole grade cows; progesterone; protein supplementation; reproduction

\section{INTRODUCTION}

Bos indicus is the majority of cattle raised by Indonesian farmers, especially Ongole Grade cows as a predominant breed in Java, Indonesia. Ongole Grade cow is considered as a highly resistant cow to high temperature and humidity, as well as to parasitic infections. Despite their good adaptabilities to heat and nutritional stress, this indigenous cattle encounters a short length of estrous. Unable to detect estrous signs in their short estrous period is a serious problem for farmers because it prolongs the time of cows to be pregnant, increases calving interval, and consequently delays the time at producing offspring (Ratnawati et al., 2017). Irrespective of the level of farmer knowledge and experience, promoting estrous behavior and signs to be easily detected is important to define the insemination time that can reduce calving interval and increase reproduction efficiency.

There are many factors influencing estrous signs, including breed, age, physical and physiological conditions, environment, and nutritional aspects (Moran et al., 2010). Among these factors, nutrient plays an important role in supporting the reproductive performance, in particular for cattle that are traditionally reared by smallholder farmers, whereas inadequacy of nutrient supply becomes one of the major constraints (Astuti et al., 2019). Therefore, providing concentrate to alleviate protein concentration for cattle is a common practice to ensure nutrient sufficiency to support optimal animal growth and puberty (Gading et al., 2020).

The relationships between nutrient consumption and reproductive performance of ruminant have been comprehensively reviewed by Robinson et al. (2006). 
Unfortunately, so far, protein recommendation is only available for growth and maintenance requirements (NRC, 2000). Little is known regarding the specific protein requirement for reproduction functions, such as ovarian function and estrous behavior of ruminants. Regarding the role of protein in reproduction, the common consensus is that protein deficiency may impair the estrous expression of cattle (Robinson, 2006). In addition, protein deficiency also negatively affects reproductive hormone profiles such as insulin-like growth factor 1 (IGF1), estradiol 17 $\beta$, and progesterone, which results in changes in ovarian function (Diskin \& Kenny, 2016). Since Ongole Grade Cows are commonly fed native grass and rice straw which have low protein contents, their reproductive performances may be impaired.

To date, a large number of studies have reported the effect of dietary protein concentrate on estrous behavior and reproductive performance of dairy cattle (Law et al., 2009) and beef cattle (Rosales-Torres et al., 2016; Sonjaya et al., 2020). However, there are high variabilities of duration, signs, and intensity of the displayed estrous among individuals and breeds (Moran et al., 2010). Therefore, a study evaluating the effect of protein concentrate on the estrous signs for specific local cattle is demanding. Moreover, females may exhibit different behavioral signs of estrous depending on physiological condition, age, and management (Mondal et al., 2006). In some breeds of cattle, including Bos indicus, difficulty in detecting estrous was reported because of short estrous behavior that mainly visible during late night, giving a consequence to reproductive failure and inefficiency (Dung et al., 2019).

Estrous synchronization and fixed-time artificial insemination (TAI) have been successfully implemented to improve the productivity and profitability of farmers (Dahlen et al., 2014). Estrous synchronizations using hormonal intervention such as PGF $2 \alpha$ and GnRH were reported to increase fertilization and pregnancy rates (Bishop et al., 2017; Kasimanickam et al., 2020). The PGF $2 \alpha$ is used to regress corpus luteum, which subsequently induces ovulation and ripening of the follicles (Kasimanickam et al., 2020). Since the success of estrous synchronization should be supported by a sufficient nutrition, evaluation of the level of protein supplementation at specific age of synchronized Ongole Grade cows is needed to evaluate the effect of concentrate CP levels as feed supplement on different ages of Ongole Grade cows on estrous signs and progesterone concentrations.

\section{MATERIALS AND METHODS}

\section{Animal and Experimental Design}

The use of experimental animals in this study was approved by the ethics committee of Animal Welfare Commission of Indonesia Agency for Agricultural Research and Development (No: Balitbangtan/BPTP Jateng/RM/19/2017). No clinical disorders were observed during the experimental period.

This experiment was conducted at Central of Animal Husbandry and Livestock Integration in Central
Java Province, Indonesia, from July to December 2017. Females Ongole Grade cattle $(n=30)$ with an average weight of $250.5 \pm 35.72 \mathrm{~kg}$ were divided into two groups according to their ages (first group as G1 were $25 \pm 1.6$ months, $n=15$; second group as G2 were $37 \pm 1.7$ months, $\mathrm{n}=15$ ). The animals were individually reared on individual pen and received $3 \mathrm{~kg} / \mathrm{head} /$ day of concentrate, king grass (Pennisetum purpureum) and rice straw with the proportion of $15 \%$ and $52.5 \%$, respectively, at approximately 07.00 PM, fed as Total Mixed Ration (TMR). Dietary treatments were provided at 14 day prior to the synchronization. The treatments were 3 dietary TMR differing in $\mathrm{CP}$ levels (T1= TMR with $7.41 \% \mathrm{CP}$; T2= TMR with $8.23 \% \mathrm{CP}$; and $\mathrm{T} 3=\mathrm{TMR}$ with $9.17 \% \mathrm{CP} ; 5$ animals per treatment were used as replication). Chemical composition of individual feedstuff is presented in Table 1, while composition of dietary treatments is provided in Table 2. Nutrient intakes, including DM, CP, and TDN were calculated weekly by weighing the residual feed. The chemical composition of each material was analyzed according to the Association of Official Analytical Chemists (AOAC, 2005) for dry matter (DM, method 973.18), organic matter (OM; method 942.05), ether extract (EE, method 920.39), crude protein (CP, method 984.13), and crude fiber (CF, method 978.10) contents. The DM content was determined using a conventional oven at $105^{\circ} \mathrm{C}$, while the OM content was determined by ashing the samples in a furnace at $550^{\circ} \mathrm{C}$ for $16 \mathrm{~h}$. Kjeldhal method was used to quantify total $\mathrm{N}$ then the $\mathrm{CP}$ content was calculated by multiplying the total $\mathrm{N}$ with 6.25 . The $\mathrm{CF}$ content was determined by boiling the samples in $1.25 \% \mathrm{H}_{2} \mathrm{SO}_{4}$ and $1.25 \% \mathrm{NaOH}$, while the $\mathrm{EE}$ content was determined using petroleum ether as the organic solvent.

The estrus cycles of the experimental animals were synchronized with a 2-mL intramuscular injection of prostaglandin F2 $\alpha$ (PGF2 $\alpha$, Lutaprost ${ }^{\circledR}$ 250, Agrovet, SENASA Perú: F.16.01.N.0139) on d-3 prior to time-fixed artificial insemination (TAI), followed with $1.25-\mathrm{mL}$ injection of gonadotropin-releasing hormone (GnRH, Conceptase, Agrovet, SENASA Perú: F.16.01.N.0136) on d-2. Insemination was conducted for cows showing estrous signs by the same technician, using frozen semen from the same breed of bull. Synchronization was reconducted on $\mathrm{d}+11$ for cows that did not show estrous signs in the first induction and were inseminated on $\mathrm{d}+14$. The timeline of synchronization and TAI program was provided in Figure 1.

Estrous signs were evaluated by visual observation according to estrous behavior every $6 \mathrm{~h}$ which each observation was conducted for $30 \mathrm{~min}$. Visual detection was conducted by observing the estrous signs such as vulva redness, wet swollen, and mucus discharge. The score was given for each sign according to the method of Layek et al. (2011), whereas the scores obtained from each of the behavioral signs of each animal were averaged to indicate the estrous level. The final scores were classified into three estrous levels: $1=$ less visible estrous symptoms, $2=$ quite visible estrous symptoms, and $3=$ visible estrous symptoms. These scores were used to decide whether the cows were in estrous or not (Table 3). 
Table 1. Chemical composition of individual raw material used in the study

\begin{tabular}{|c|c|c|c|c|c|}
\hline \multirow{2}{*}{ Nutrient composition (\%) } & \multicolumn{3}{|c|}{ Concentrate } & \multirow{2}{*}{ KG } & \multirow{2}{*}{ RS } \\
\hline & $\mathrm{C} 1$ & $\mathrm{C} 2$ & $\mathrm{C} 3$ & & \\
\hline Dry matter & 89.00 & 89.30 & 88.50 & 17.20 & 86.02 \\
\hline Ether extract & 4.42 & 3.59 & 4.47 & 2.46 & 2.96 \\
\hline Crude protein & 11.62 & 14.15 & 17.02 & 7.56 & 4.75 \\
\hline Crude fiber & 19.72 & 21.08 & 18.87 & 34.92 & 31.39 \\
\hline Ash & 8.14 & 7.37 & 12.39 & 18.50 & 19.20 \\
\hline Nitrogen free extract & 56.17 & 59.54 & 53.24 & 37.72 & 37.45 \\
\hline Total digestible nutrient ${ }^{*}$ & 53.40 & 72.81 & 60.97 & 53.71 & 57.69 \\
\hline
\end{tabular}

Note: $\mathrm{KG}=$ King grass; $\mathrm{RS}=$ Rice straw; $\mathrm{C} 1=$ concentrate with $11.62 \%$ crude protein $(\mathrm{CP}) ; \mathrm{C} 2=$ concentrate with $14.15 \% \mathrm{CP}$; and $\mathrm{C} 3=$ concentrate with $17.02 \%$ CP. ${ }^{*}$ Calculated according to Hartadi et al. (2005).

Table 2. Diet composition and chemical composition of dietary treatment used in the study

\begin{tabular}{lrrr}
\hline \multirow{2}{*}{ Diet composition } & \multicolumn{3}{c}{ Proportion (\% DM) } \\
\cline { 2 - 4 } & $\mathrm{T} 1$ & $\mathrm{~T} 2$ & 32.5 \\
Concentrate $^{1}$ & 32.5 & 32.5 & 15.0 \\
King grass (Pennisetum purpureum) & 15.0 & 15.0 & 52.5 \\
Rice straw & 52.5 & 52.5 & 76.69 \\
Chemical composition (\%) & & & 3.38 \\
Dry matter (\%) & 76.86 & 76.96 & 9.17 \\
Ether extract (\%) & 3.36 & 3.09 & 27.82 \\
Crude protein(\%) & 7.41 & 8.23 & 16.87 \\
Crude fiber (\%) & 28.10 & 28.54 & 42.65 \\
Ash (\%) & 15.48 & 15.23 & 58.18 \\
Nitrogen free extract (\%) & 43.60 & 44.70 & 62.04 \\
Total digestible nutrient ${ }^{2}(\%)$ & 55.70 & & \\
\hline
\end{tabular}

Note: $\mathrm{T} 1=$ toal mixed ration (TMR) with $7.41 \%$ crude protein $(\mathrm{CP})$; $\mathrm{T} 2=\mathrm{TMR}$ with $8.23 \% \mathrm{CP}$; and $\mathrm{T} 3=\mathrm{TMR}$ with $9.17 \% \mathrm{CP} .{ }^{1=C}$ Composition of concentrate was rice bran, wheat bran, and coffee pulp; ${ }^{2}$ Calculated according to Hartadi et al. (2005).

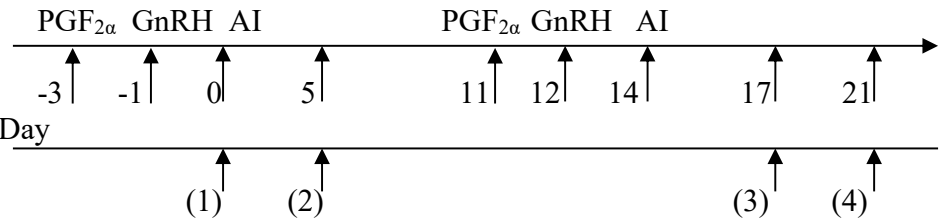

Figure 1. Timeline of blood collection

\section{Blood Sampling and Hormone Analysis}

Blood samples were collected regularly from three cows per group using the caudal venipuncture on day 1 , 5, 17, and 21 after AI (Figure 1) into 10-mL heparinized blood collection tubes (EDTA tubes). The samples were then incubated at $-4^{\circ} \mathrm{C}$ for $12-24 \mathrm{~h}$ before centrifugation ( $2500 \times g$ for $10 \mathrm{~min}$ ) to obtain the blood plasma. The plasma samples were transferred into micro tubes after centrifugation and stored at $-20^{\circ} \mathrm{C}$ until being assayed (Barnwell et al., 2015). Progesterone concentrations in the samples were determined by ELISA method using standard monoclonal antibody kits as previously described by Broes \& LeBlanc (2014) with coefficients of variation $(\mathrm{CV})$ of $10.5 \%$.

\section{Statistical Analysis}

This study used a randomized complete block design with a $2 \times 3$ factorial arrangement. There were two age groups (G1 and G2) in which each group was divided into three dietary TMR with different CP levels treatments (T1, T2, and T3). Each group was replicated five times. Data of nutrient intake and progesterone concentration were subjected to a randomized complete block design of ANOVA followed by Duncan's Multiple Range Test (DMRT) to compare means among treatment groups. In regard to data of estrous signs, the KruskalWallis test was conducted to compare means among dietary concentrate treatments while data between age groups were compared by using an independent t-test. In addition, percentages of estrous were compared descriptively (Sutiyono et al., 2018). Significance was de- 
clared at $\mathrm{p}<0.05$ both for parametric and non-parametric tests.

\section{RESULTS}

\section{Feed Intake}

Effects of dietary TMR treatment and age group of cows and their interactions are presented in Table 3. The CP and TDN intakes in this study showed a similar trend in which significant interactions were found on $\mathrm{CP}$ and TDN intakes $(\mathrm{p}<0.01)$. The highest CP and TDN intakes were observed in older cows (G2) fed TMR with $7.41 \%$ CP (T1) and were significantly higher compared with the other treatments $(\mathrm{p}<0.01)$. The highest TDN intake in older cows (G2) fed TMR with $7.41 \%$ CP (T1) as was observed in this study can be associated with the highest $\mathrm{CP}$ intake in this treatment group. However, DM intake was similar among treatments, and there was no interaction detected between experimental factors $(\mathrm{p}>0.05)$.

\section{Estrous Signs}

In this present study, estrous symptoms were observed from three major visual characteristics (vulva redness, swollen vulva, and mucus discharge). Average estrous scores for each sign are provided in Table 4, while the estrous percentage is presented in Table 5. The average scores of estrous ranged between 1.11 and 1.48, indicating that there was a relatively less visible sign of estrous for all groups of cattle. According to the age group, older cattle (G2) showed a significantly higher intensity of estrous, as was shown by the higher scores of vulva redness, swollen vulva, and mucus discharge. This incidence was in line with the higher estrous percentage for the older group $(80 \%$ vs $73 \%$, respectively, Table 5). On the other hand, dietary concentrate with different crude protein levels did not show any significant effect on estrous signs. However, the descriptive analysis suggested that cattle receiving TMR with the highest CP level $(9.17 \%$ in $\mathrm{T} 3)$ resulted in a higher estrous percentage than that of the control group $(80 \%$ vs $70 \%$, respectively, Table 5).

\section{Progesterone Concentration}

Progesterone concentration was assessed 4 times on days $1,5,17$, and 21 post $\mathrm{AI}$, and the results are shown in Table 6. In the initial assessment conducted on day 1 , the progesterone concentrations in cows fed TMR with 9.17\% CP (T3) were found to be significantly higher than

Table 3. Different age groups and dietary concentrate supplementations and their interactions on nutrients intake ( $\mathrm{n}=5$ cows per dietary treatment; $\mathrm{n}=15$ per age group treatment)

\begin{tabular}{|c|c|c|c|c|c|}
\hline \multirow{2}{*}{ Variables } & \multirow{2}{*}{ Age group } & \multicolumn{3}{|c|}{ Dietary treatment } & \multirow{2}{*}{ Average } \\
\hline & & $\mathrm{T} 1$ & $\mathrm{~T} 2$ & T3 & \\
\hline \multirow[t]{3}{*}{ DM intake (\% BW) } & G1 & $3.39 \pm 0.70$ & $4.11 \pm 0.15$ & $3.03 \pm 0.33$ & $3.51 \pm 0.07$ \\
\hline & G2 & $4.56 \pm 0.33$ & $4.00 \pm 0.39$ & $3.78 \pm 0.09$ & $4.11 \pm 0.44$ \\
\hline & Average & $3.91 \pm 4.99$ & $4.02 \pm 0.69$ & $3.81 \pm 0.26$ & \\
\hline \multirow[t]{3}{*}{ CP Intake (kg/day) } & G1 & $0.23 \pm 0.04^{c}$ & $0.24 \pm 0.00^{\mathrm{bc}}$ & $0.26 \pm 0.02^{b}$ & $0.24 \pm 0.04 y$ \\
\hline & G2 & $0.32 \pm 0.02^{\mathrm{a}}$ & $0.25 \pm 0.02^{\mathrm{b}}$ & $0.26 \pm 0.00^{\mathrm{b}}$ & $0.27 \pm 0.04^{x}$ \\
\hline & Average & $0.28 \pm 0.02 q$ & $0.25 \pm 0.02^{\mathrm{pq}}$ & $0.26 \pm 0.03 p$ & \\
\hline \multirow[t]{3}{*}{ TDN intake (kg/day) } & G1 & $2.01 \pm 0.48^{\mathrm{b}}$ & $2.18 \pm 0.21^{\mathrm{b}}$ & $2.11 \pm 0.21^{\mathrm{b}}$ & $2.10 \pm 0.30 y$ \\
\hline & G2 & $2.62 \pm 0.17^{a}$ & $2.17 \pm 0.22^{\mathrm{b}}$ & $2.12 \pm 0.12^{\mathrm{b}}$ & $2.31 \pm 0.18^{x}$ \\
\hline & Average & $2.31 \pm 0.32 q$ & $2.18 \pm 0.21 p$ & $2.12 \pm 0.17^{\mathrm{pq}}$ & \\
\hline
\end{tabular}

Note: Means in the same column with different superscripts differ signifcantly $(\mathrm{p}<0.05) ; \mathrm{T}=\mathrm{CP}$ levels of the TMR effect; $\mathrm{DM}=\mathrm{dry}$ matter; $\mathrm{CP}=\mathrm{crude}$ protein; TDN=total digestible nutrient; $\mathrm{T} 1=$ total mixed ration $(\mathrm{TMR})$ with $7.41 \% \mathrm{CP}$; $\mathrm{T} 2=\mathrm{TMR}$ with $8.23 \% \mathrm{CP}$; and $\mathrm{T} 3=\mathrm{TMR}$ with $9.17 \% \mathrm{CP}$; $\mathrm{G} 1=$ age group; G2= age group 2.

Table 4. Average scores of estrous signs at different ages and dietary concentrate supplementations

\begin{tabular}{lcccc}
\hline \multirow{2}{*}{ Treatments } & & \multicolumn{3}{c}{ Estrous signs } \\
\cline { 3 - 5 } & & Vulva redness & Swollen vulva & Mucus discharge \\
\hline Age group & G1 & $1.21 \pm 0.18^{\mathrm{b}}$ & $1.21 \pm 0.18^{\mathrm{b}}$ & $1.11 \pm 0.11^{\mathrm{b}}$ \\
& G2 & $1.47 \pm 0.29^{\mathrm{a}}$ & $1.41 \pm 0.25^{\mathrm{a}}$ & $1.28 \pm 0.18^{\mathrm{a}}$ \\
Dietary treatment $^{\mathrm{ns}}$ & & & & \\
& T1 & $1.28 \pm 0.19$ & $1.26 \pm 0.16$ & $1.14 \pm 0.13$ \\
& T2 & $1.33 \pm 0.31$ & $1.30 \pm 0.27$ & $1.22 \pm 0.21$ \\
& T3 & $1.42 \pm 0.29$ & $1.37 \pm 0.26$ & $1.22 \pm 0.16$ \\
\hline
\end{tabular}

Note: Means in the same column with different superscripts differ signifcantly $(\mathrm{p}<0.05)$ according to independent $\mathrm{t}$-test; ${ }^{\mathrm{n}}=\mathrm{not}$ significant at $\mathrm{p}<0.05$ according to Kruskal-Wallis test; $0.00-1.00=$ less visible estrus signs; $1.01-2.00=$ quite visible estrus signs; $2.01-3.00=$ visible estrus signs; T1= total mixed ration $(\mathrm{TMR})$ with $7.41 \%$ crude protein $(\mathrm{CP})$; T2= TMR with $8.23 \% \mathrm{CP}$; and T3= TMR with 9.17\% CP; G1= age group; G2= age group 2 . 
Table 5. Estrous percentage and number of estrous' animals at different age groups and dietary concentrate supplementations

\begin{tabular}{|c|c|c|c|c|}
\hline \multirow{2}{*}{ Age group } & \multicolumn{3}{|c|}{ Dietary treatment } & \multirow{2}{*}{ Average } \\
\hline & $\mathrm{T} 1$ & $\mathrm{~T} 2$ & T3 & \\
\hline \multirow[t]{2}{*}{ Group 1 (G1) } & $60 \%$ & $80 \%$ & $80 \%$ & $73 \%$ \\
\hline & $6 / 10^{*}$ & $8 / 10$ & $8 / 10$ & $22 / 30$ \\
\hline \multirow[t]{2}{*}{ Group 2 (G2) } & $80 \%$ & $80 \%$ & $80 \%$ & $80 \%$ \\
\hline & $8 / 10$ & $8 / 10$ & $8 / 10$ & $24 / 30$ \\
\hline \multirow[t]{2}{*}{ Average } & $70 \%$ & $80 \%$ & $80 \%$ & \\
\hline & $14 / 20$ & $16 / 20$ & $16 / 20$ & \\
\hline
\end{tabular}

Note: ${ }^{*}=$ number of estrous' animals; $\mathrm{T} 1=$ total mixed ration $(\mathrm{TMR})$ with $7.41 \%$ crude protein $(\mathrm{CP}) ; \mathrm{T} 2=\mathrm{TMR}$ with $8.23 \% \mathrm{CP}$; and $\mathrm{T} 3=\mathrm{TMR}$ with $9.17 \%$ CP.

Table 6. Progesteron concentrations $(\mathrm{ng} / \mathrm{mL})$ of the experimental animals at different age groups and dietary concentrate supplementations

\begin{tabular}{|c|c|c|c|c|c|}
\hline \multirow{2}{*}{$\begin{array}{c}\text { Days of measurement } \\
\text { after AI }\end{array}$} & \multirow{2}{*}{ Age group } & \multicolumn{3}{|c|}{ Dietary treatment } & \multirow{2}{*}{ Average } \\
\hline & & $\mathrm{T} 1$ & $\mathrm{~T} 2$ & $\mathrm{~T} 3$ & \\
\hline \multirow[t]{3}{*}{ Day 1} & G1 & $0.23 \pm 0.00^{c}$ & $6.11 \pm 0.42^{\mathrm{ab}}$ & $7.21 \pm 0.56^{\mathrm{a}}$ & $4.52 \pm 0.39$ \\
\hline & G2 & $3.85 \pm 0.29 \mathrm{~b}$ & $4.71 \pm 0.34^{\mathrm{b}}$ & $7.06 \pm 0.53^{\mathrm{a}}$ & $5.21 \pm 0.47$ \\
\hline & Average & $2.07 \pm 0.09 q$ & $5.41 \pm 0.28^{p q}$ & $7.13 \pm 0.56^{p}$ & \\
\hline \multirow[t]{3}{*}{ Day 5} & G1 & $6.46 \pm 0.60^{d}$ & $21.73 \pm 1.87^{b}$ & $29.21 \pm 2.58^{\mathrm{a}}$ & $19.13 \pm 2.14^{x}$ \\
\hline & G2 & $6.14 \pm 0.72^{\mathrm{d}}$ & $11.09 \pm 0.82^{c}$ & $28.95 \pm 2.51^{\mathrm{a}}$ & $15.39 \pm 1.46^{y}$ \\
\hline & Average & $6.30 \pm 0.51^{\mathrm{r}}$ & $16.40 \pm 1.16^{q}$ & $29.09 \pm 1.87 \mathrm{p}$ & \\
\hline \multirow[t]{3}{*}{ Day 17} & G1 & $9.81 \pm 1.02^{\mathrm{c}}$ & $22.76 \pm 1.76^{\mathrm{b}}$ & $38.99 \pm 4.06^{\mathrm{a}}$ & $23.85 \pm 2.61^{x}$ \\
\hline & G2 & $9.63 \pm 0.85^{c}$ & $19.38 \pm 2.13^{b}$ & $25.72 \pm 2.85^{\mathrm{b}}$ & $18.24 \pm 1.92^{\mathrm{y}}$ \\
\hline & Average & $9.72 \pm 1.01^{\mathrm{r}}$ & $21.07 \pm 1.82^{q}$ & $32.36 \pm 2.14 p$ & \\
\hline \multirow[t]{3}{*}{ Day 21} & G1 & $13.22 \pm 1.47^{c}$ & $21.43 \pm 1.94^{\mathrm{b}}$ & $28.11 \pm 3.16^{\mathrm{a}}$ & $20.92 \pm 1.87^{x}$ \\
\hline & G2 & $12.18 \pm 2.02^{c}$ & $14.94 \pm 1.56^{\mathrm{bc}}$ & $25.19 \pm 3.01^{\mathrm{a}}$ & $17.44 \pm 1.39 y$ \\
\hline & Average & $12.70 \pm 1.02^{\mathrm{r}}$ & $18.19 \pm 1.43 q$ & $26.65 \pm 1.92 \mathrm{p}$ & \\
\hline
\end{tabular}

Note: Means in the same column with different superscripts differ signifcantly ( $<<0.05)$; $\mathrm{T} 1=$ total mixed ration $(\mathrm{TMR})$ with $7.41 \%$ crude protein $(\mathrm{CP})$; $\mathrm{T} 2=\mathrm{TMR}$ with $8.23 \% \mathrm{CP}$; and $\mathrm{T} 3=\mathrm{TMR}$ with $9.17 \% \mathrm{CP} ; \mathrm{G} 1=$ age group; $\mathrm{G} 2=$ age group 2 .

in those fed TMR with $7.41 \%$ CP (T1) in both age group $(\mathrm{p}<0.05)$. However, there was no difference found in the progesterone concentrations between younger (G1: 25 months) and older (G2: 37 months) cows ( $>00.05)$. On the other hand, there were significant interaction effects between age group and $\mathrm{CP}$ content of dietary treatment on progesterone concentrations on days 5, 17, and 21 of sampling periods $(\mathrm{p}<0.01)$. Among treatment groups, feeding dietary treatment offered as TMR contained 9.17\% CP (T3) in young cows (G1: 25 months) resulted in the highest progesterone concentration as was observed on days 17 and 21 compared with the other treatments $(p<0.01)$. However, on day 5, different trends of progesterone concentrations were observed where cows fed TMR with $9.17 \%$ CP (T3) on both age groups had similar concentrations $(p>0.05)$, and the values were the highest among the other treatments $(p<0.05)$.

\section{DISCUSSION}

The dry matter intakes for both age groups in this study were similar and were in the normal range according to the minimum requirement (NRC, 2000) that was approximately 3\% of BW. Generally speaking, animals, including beef cattle, have a regulatory mechanism to control their needs for nutrient consumption to maintain normal physiological functions (McDonald et al., 2011). Similar intakes of DM and OM in this study revealed that the offered diets were in acceptable amounts. Chen et al. (2012) reported that cows fed 10\% and $12 \% \mathrm{CP}$ diet did not affect DM intake. The highest $\mathrm{CP}$ and TDN intakes in older cows (G2) fed TMR with $7.41 \%$ CP (T1) in this study was strongly related to the DM intake. Although the DM intakes were similar among the experimental groups, $\mathrm{CP}$ intakes that were calculated based on DM showed to be significant. These different CP intakes are possible due to the lower variance in individual $\mathrm{CP}$ intake. As a consequence, TDN intake was also influenced. There is evidence that hormone regulation in different ages, sexes, and breeds plays an important role in cows feeding behavior. Cows with older age are more stable in hormonal change and temperament and have larger gut capacities (Riaz et al., 2014; Puzio et al., 2019). Another possible reason why older cows (G2) fed TMR with the lowest CP percentage (T1) had the highest CP and TDN intakes could be related to the ability of the cows to control their consumption needs. Cows fed a similar diet form but with lower nutritional content tend to consume in a higher amount to meet their nutrient demands (McDonald et al., 2011).

Lack of estrous detection remains a major obstacle faced by the traditional farmer, which directly affects the success of reproduction. Therefore, sufficient knowledge in assessing estrous signs and behavior is crucial 
for efficient reproductive management (Shirasuna, 2010). Observations showed that estrous cattle exhibited more obvious signs of cervical mucus discharge and vulva redness. Other behavioral signs were more frequent urinating, restlessness, and bellowing (Schubach et al., 2017). Among multiple factors, nutrient deficiency contributes to the vast majority of problems with estrous detection, especially when fibrous crops with low protein contents are a major component of the diet. In this study, supplementation of non-fibrous material differing in protein contents was aimed to evaluate the effects of different levels of protein in the concentrate on the reproductive performance of Ongole Grade cows. According to previous discussions, the high level of protein consumption can improve fertility and reproductive performance, although the evidence on the threshold level is not clear and varies among breeds (Geppert et al., 2017).

In the present study, the higher percentage of estrous was confirmed in cows fed concentrate with higher protein concentration, although the intensities between dietary treatments were similar. Apart from the estrous intensity, offering TMR with higher CP content, as shown in cows in groups T2 $(8.23 \%)$ and C3 $(9.17 \%)$ resulted in a beneficial effect for promoting higher estrous percentage. To our knowledge, providing sufficient nutrients can enhance ovarian function (Geppert et al., 2017). Another suggestion stated that in the condition of normal ovarian function, nutrient status did not interfere with estrous signs and behavior (Orihuela, 2000). The results of the present study confirmed these explanations since cows fed TMR with the highest $\mathrm{CP}$ concentration of $9.17 \%$ (C3) did not show different estrous signs but increase estrous percentage because the TDN (58.18\%) and CP (9.17\%) contents of the ration at $\mathrm{T} 3$ treatment are the most appropriate nutrient requirement for postpartum beef cattle according to NRC (2000). To date, the mechanisms on how nutritional factors modulate estrous expression are still unknown (Oosthuizen et al., 2020). Therefore, further investigation in this area is required to be done. However, concerning protein intake, a theory of "higher is better" is not applicable because excessive supplementation of protein may negatively affect reproduction in cattle. This negative effect can be attributed to the role of high urea in suppressing gonadotropin release and hormone response due to the interruptions of the hypothalamus and ovarian signals. The abundance of ammonia concentration can also impair the uterine environment, which decreases fertility and reproductive performances (Lents et al., 2015).

Furthermore, the average percentage of estrous incidence in this study can be categorized as high (more than $70 \%$ ). As the cows received GnRH and PGF2 $\alpha$ synchronization, this number is logical and similar to the previous report showing more than $70 \%$ of estrous expression in cows treated with similar synchronization protocol (Rodrigues et al., 2018). The estrous expression is particularly affected by the increasing level of circulating estradiol hormone, which induces the hypothalamic initiation leading to the onset of estrous expression
(Silper et al., 2015; Schubach et al., 2017). Frandson (2003) reported that estrogen stimulated the thickening of the vaginal wall, increased vascularization, and stimulate the outer genitalia to be swollen, reddish, and increased vaginal secretions. In cows that did not show estrous symptoms may be attributable to the under-threshold level of estrogen concentration that was not sufficient to stimulate and release estrous symptoms. Unestrous cows were pale, dry, not swollen, and did not release mucus.

In addition, there was an effect of age on the percentage of estrous expression by the cows where the older group cows showed a higher intensity of estrous. This result was in agreement with the observation of Orihuela (2000), who explained that older cows showed a longer estrous duration and higher estrous intensity than heifers or nulliparous cows. This condition is related to the reality that older cows will have a greater size of the ovary that can produce a higher level of estrogen. Estrogen concentration plays an important role in the estrous intensity and estrous signs.

The average progesterone concentrations on the first day of AI were below $2 \mathrm{ng} / \mathrm{mL}$ in all groups of herds (Table 6). Low concentrations of progesterone in the experimental cows may be due to the fewer number of granulose cells, the reduced concentrations of LH receptors on granulose cells to synthesize adequate progesterone after luteinization. As previously performed by Hankele et al. (2020), concentrations of all progesterone metabolites were low during the estrous period and increased following quadratic patterns in response to fertilization and follicle growth. Supporting this reason, Alves et al. (2011) suggested that high estrogen concentration during the follicular phase promotes a low level of progesterone. On the day 5, progesterone concentrations increased at $2 \mathrm{ng} / \mathrm{mL}$ on all groups. This increase was due to the optimum CL function (Moore et al., 2014). This increase in progesterone concentration was also an indication of a positive effect of progesterone on embryonic development and pregnancy strengthening. Smaller size of corpus luteum (CL) is a factor determining the lower progesterone concentration. Therefore, increasing CL size in the older cattle increases progesterone production (Moore et al., 2014).

Furthermore, the concentrations of progesterone reached the highest levels on $\mathrm{d} 17$ and experienced a non-substantial decrease thereafter until day 21, which was maintained and decreased at a particular degree due to pregnancy. The dynamic of progesterone levels showed a quadratic trend during estrous, diestrous, and proestrus following the physiological reproduction during this period in which the concentration reached the highest levels during days 11 to 17 after estrous (Alves et al., 2011). Adequate circulating concentrations of progesterone during diestrous are required to stimulate endometrial secretions, which are essential for embryonic implantation, development and survival, maternal recognition, and maintenance of pregnancy (Spencer et al., 2016).

Hormonal changes, especially progesterone, were occurred when the animals experience estrous symptoms, whereas the progesterone level will increase at 
post-estrous compared with during estrous and preestrous stage (Ramachandran et al., 2020). The result of this study also showed that older cows produced a greater concentration of progesterone (Table 6). It was previously explained that estrous behavior had a positive relation with age and parity (Frade et al., 2014). Additionally, concentrate supplementation did not affect progesterone profile on day 1 to day 17 . These results suggest that the higher level of protein supplementation may not be beneficial in improving pregnancy as long as the level of supplementation provides a positive energy balance.

\section{CONCLUSION}

The present study confirmed that on Ongole Grade cows, older cows receiving low CP diets would consume higher, thus resulted in the highest CP and TDN intakes. Conversely, progesterone concentration was the highest in younger cows fed high CP diet as it was indicated in younger cows (G1) fed TMR with 9.17\% $\mathrm{CP}$ content (T3). This study also demonstrated that the older group of cows showed higher estrous intensity than those of younger age that were mainly primiparous cattle. However, the dietary treatments did not affect estrous intensity as was observed with similar scores obtained from all indicators used in this study, including vulva redness, wet swollen of the vulva, and mucus discharge.

\section{CONFLICT OF INTEREST}

We certify that there is no conflict of interest with any financial, personal, or other relationships with other people or organizations related to the material discussed in the manuscript.

\section{ACKNOWLEDGMENT}

The authors are grateful to the Central of Animal Husbandry and Livestock Integration in Central Java for infrastructure and animal care. Authors also thank Indonesia Agency for Agricultural Research and Development, Ministry of Agriculture, Indonesia by providing funding to conduct this study.

\section{REFERENCES}

Alves, N. G., C. A. A. Torres, J. D. Guimarães, E. A. Moraes, M. T. Rodrigues, P. R. Cecon, L. L. Bitencourt, \& L. D. S. Amorim. 2011. Effect of urea in the diet on ovarian follicular dynamics and plasma progesterone concentration in Alpine goats. R. Bras. Zootec. 40: 1512-1518. https://doi. org/10.1590/S1516-35982011000700016

AOAC. 2005. Official Methods of Analysis of AOAC International. 18th ed. Assoc. Off. Anal. Chem., Arlington.

Astuti, D., B. Suhartanto, N. Umami, \& A. Irawan. 2020. Productivity, nutrient composition, and hydrocyanic acid concentration of Super-2 forage sorghum at different NPK levels and planting spaces. Trop. Anim. Sci. J. 42:189-195. https://doi.org/10.5398/tasj.2019.42.3.189

Bishop, B. E., J. M. Thomas, J. M. Abel, S. E. Poock, M. R. Ellersieck, M. F. Smith \& D. J. Patterson. 2017. Split-time artificial insemination in beef cattle: III. Comparing fixedtime artificial insemination to split-time artificial insemination with delayed administration of $\mathrm{GnRH}$ in postpartum cows. Theriogenology. 99:48-52. https://doi.org/10.1016/j. theriogenology.2017.04.046

Broes, A. \& S. J. LeBlanc. 2014. Comparison of commercial progesterone assays for evaluation of luteal status in dairy cows. Can. Vet. J. 55: 582-584.

Chen, S., P. Paengkoun, \& X. Xia. 2012. Effect of dietary crude protein and undegradable intake protein on nitrogen utilization and growth performance of groeing Thaiindogenous beef cattle. Trop. Anim. Health Prod. 51:11511159. https://doi.org/10.1007/s11250-019-01799-0

Dahlen, C., J. Larson, \& G. C. Lamb. 2014. Impacts of reproductive technologies on beef production in the United States. Current and Future Reproductive Technologies and World Food Production. Springer, New York, NY, USA, pp. 97114. https://doi.org/10.1007/978-1-4614-8887-3_5

Diskin, M. G. \& D. A. Kenny. 2016. Managing the reproductive performance of beef cows. Theriogenology. 86:379-387. https://doi.org/10.1016/j.theriogenology.2016.04.052

Dung, D. V., H. Roubík, L. D. Ngoan, L. D. Phung, \& N. X. Ba. 2019. Characterization of smallholder beef cattle production system in Central Vietnam -revealing performance, trends, constraints, and future development. Trop. Anim. Sci. J. 42: 253-260. https://doi.org/10.5398/tasj.2019.42.3.253

Frade, M. C., C. Frade, M.B. Cordeiro, M.F. Sá Filho, F.S. de, Mesquita, G. Nogueira, P. de, M. Binelli, \& C.M.B. Membrive. 2014. Manifestation of estrous behavior and subsequent progesterone concentration at timed-embryo transfer in cattle are positively associated with pregnancy success of recipients. Anim. Reprod. Sci. 151:85-90. https:// doi.org/10.1016/j.anireprosci.2014.09.005

Frandson, R. D, W. L. Wilke, \& A. D. Fails. 2003. Anatomy and Physiology of Farm Animal. $7^{\text {th }}$ ed. Lippincott Williams and Wilkins, Philadelphia.

Gading, M. B. W. T., A. Agus, A. Irawan, \& P. Panjono. 2020. Growth performance, hematological and mineral profile of post-weaning calves as influenced by inclusion of pelleted-concentrate supplement containing essential oils and probiotics. Iran. J. Appl. Anim. Sci. 10:461-468.

Geppert, T. C., A. M. Meyer, G. A. Perry, \& P. J. Gunn. 2017. Effects of excess metabolizable protein on ovarian function and circulating amino acids of beef cows: 2. Excessive supply in varying concentrations from corn gluten meal. Animal. 11: 634-642. https://doi.org/10.1017/ S1751731116001890

Kasimanickam, R., K. Jorgensen-Muga, J. Beumeler, K. Ratzburg, A. Kapi, V. Kasimanickam \& J. Kastelic. 2020. Estrous response and pregnancy percentages following use of a progesterone-based, split-time estrous synchronization treatment regimens in beef heifers. Anim. Reprod. Sci. 221:106544. https://doi.org/10.1016/j. anireprosci.2020.106544

Layek, S. S., T. K. Mohanty, A. Kumaresan, K. Behera, \& S. Chand. 2011. Behavioural signs of estrous and their relationship to time of ovulation in Zebu (Sahiwal) cattle. Anim. Reprod. Sci. 129:140-145. https://doi.org/10.1016/j. anireprosci.2011.11.006

Law, R. A., F. J. Young, D. C. Patterson, D. J. Kilpatrick, A. R. G. Willie, \& C. S. Mayne. 2009. Effect of dietary protein content on the fertility of dairy cows during early and mid lactation. J. Dairy Sci. 92:2737-2746. https://doi.org/10.3168/ jds.2008-1420

Lents, C. A., F. J. White, N. H Ciccioli, R. P Wettemann, L. J. Spicer, \& D . L. Lalman. 2015. Effect of body condition score at parturition and postpartum protein supplementation on estrous behavior and size of the dominant 
follicle in beef cattle. J. Anim. Sci. 86:2549-2556. https://doi. org/10.2527/jas.2008-1114

McDonald, P., R. A. Edwards, J. F. D. Greenhalgh, C. A. Morgan, L. A. Sinclair, \& R.G. Wilkinson. 2011. Animal Nutrition, $7^{\text {th }}$ ed. Pearson, Harlow.

Mondal, M., C. Rajkhowa, \& B. S. Prakash. 2006. Behavioral estrous signs can predict the time of ovulation in mithun (Bos frontalis). Theriogenology. 66:1391-1396. https://doi. org/10.1016/j.theriogenology.2006.04.033

Moore, S. G., S. Scully, J. A. Browne, T. Fair \& S. T. Butler. 2014. Genetic merit for fertility traits in Holstein cows: V. Factors affecting circulating progesterone concentrations. J. Dairy Sci. 97:5543-5557. https://doi.org/10.3168/ jds.2014-8133

Moran, C., J.F. Quirke, \& J.F. Roche. 2010. Puberty in beef heifers: A review. Anim. Reprod. Sci. 18:167-182. https://doi. org/10.1016/0378-4320(89)90019-5

NRC. 2000. Nutritional Requirements of Beef Cattle. $7^{\text {th }}$ Revised ed. The Natural Academic Press, Washington D.C.

Oosthuizen, N., R. F. Cooke, K. M. Schubach, P. L. P. Fontes, A. P. Brandão, R. V. Oliveira Filho, E. A. Colombo, G. A. Franco, S. Reese, K. G. Pohler, \& G. C. Lamb. 2020. Effects of estrous expression and intensity of behavioral estrous symptoms on variables associated with fertility in beef cows treated for fixed-time artificial insemination. Anim. Reprod. Sci. 214:106308. https://doi.org/10.1016/j. anireprosci.2020.106308

Orihuela, Â. 2000. Some factors affecting the behavioural manifestation of oestrus in cattle: a review. Appl. Anim. Behav. Sci. 70:1-16. https://doi.org/10.1016/S0168-1591(00)00139-8

Puzio, N., C. Purwin, Z. Nogalski, I. Białobrzewski, L. Tomczyk, \& J. P. Michalski. 2019. The effects of age and gender (bull vs steer) on the feeding behavior of young beef cattle fed grass silage. Asian-Australas. J. Anim. Sci. 232:1211-1218. https://doi.org/10.5713/ajas.18.0698

Ramachandran, R., A. Vinothkumar, D. Sankarganesh, U. Suriyakalaa, V. S. Aathmanathan, S. Kamalakkannan, V. Nithya, J. Angayarkanni, G. Archunan, M. A. Akbarsha, \& S. Achiraman. 2020. Detection of estrous biomarkers in the body exudates of Kangayam cattle (Bos indicus) from interplay of hormones and behavioral expressions. Domest. Anim. Endocrin. 72:106392. https://doi.org/10.1016/j. domaniend.2019.106392

Ratnawati, D., D.A. Indrakusuma, L. Affandhy, F. Cowley, D. Mayberry, \& D. Poppi. 2017. Strategi manajemen untuk meningkatkan perfomans produksi reproduksi sapi Brahman Cross (Bos indicus) di Jawa Timur, Indonesia. JITV. 21: 231-237. https://doi.org/10.14334/jitv.v21i4.1512
Riaz, M. Q., K. H. Südekum, M. Clauss, \& A. Jayanegara. 2014. Voluntary feed intake and digestibility of four domestic ruminant species as influenced by dietary constituents: a meta-analysis. Livest. Sci. 162:76-85. https://doi. org/10.1016/j.livsci.2014.01.009

Robinson, J. J., C. J. Asworth, J. A. Rooke, L. M. Mitchell, \& T. G McEvoy. 2006. Nutrition and fertility in livestock. Anim. Feed Sci. Technol. 126: 259-276. https://doi.org/10.1016/j. anifeedsci.2005.08.006

Rodrigues, A. D., R. F. Cooke, R. S. Cipriano, L. G. T. Silva, R. L. A. Cerri, \& L. H. Cruppe. 2018. Impacts of estrus expression and intensity during a timed-AI protocol on variables associated with fertility and pregnancy success in Bos indicus-influenced beef cows 1. J. Anim. Sci. 96:236249. https://doi.org/10.1093/jas/skx043

Rosales-Torres, A. M., Z. B. López-Cedillo, C. G. HernándezCoronado, J. V. Rosete-Fernández, G. D. Mendoza1, \& A. Guzmán. 2016. Short-term dietary concentrate supplementation during estrus synchronization treatment in beef cows increased IGF-I serum concentration but did not affect the reproductive response. Trop. Anim. Health Prod. 49:221-226. https://doi.org/10.1007/s11250-016-1166-7

Schubach, K. M., R. F. Cooke, A. P. Brandão, K. D. Lippolis, L. G. T. Silva, R. S. Marques, \& D. W. Bohnert. 2017. Impacts of stocking density on development and puberty attainment of replacement beef heifers. Animal. 12: 2260-2267. https://doi.org/10.1017/S1751731117001070

Shirasuna, K. 2010. Nitric oxide and luteal blood flow in the luteolytic cascade in the cow. J. Reprod. Dev. 56:9-14. https:// doi.org/10.1262/jrd.09-206E

Silper, B. F., A. M. L. Madureira, M. Kaur, T. A. Burnett, \& R. L. A. Cerri. 2015. Short communication: Comparison of estrus characteristics in Holstein heifers by 2 activity monitoring systems. J. Dairy Sci. 98:3158-3165. https://doi. org/10.3168/jds.2014-9185

Spencer, T. E., N. Forde \& P. Lonergan. 2016. The role of progesterone and conceptus-derived factors in uterine biology during early pregnancy in ruminants. J. Dairy Sci. 99:59415950. https://doi.org/10.3168/jds.2015-10070

Sonjaya, H., L. Rahim, D. K. Sari, A. Abdullah, S. Gustina, \& H. Hasbi. 2020. Estrous and pregnancy rate responses of postpartum Bali cattle to concentrate supplementation with different protein levels of rice-straw as basal ration. IOP Conf. Series: Earth and Environmental Science. 492:012075. https://doi.org/10.1088/1755-1315/492/1/012075

Sutiyono, S., D. Samsudewa, \& A. Suryawijaya. 2018. Estrus and pregnancy rate of Simmental-O'ngole crossbred and Ongole grade heifer after being synchronized and inseminated. J. Indones. Trop. Anim. Agric. 43:438-444. https:// doi.org/10.14710/jitaa.43.4.438-444 